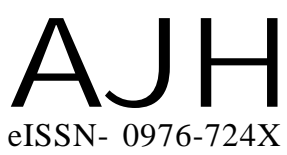
Received : 04.02.2015 Revised : 01.11 .2015 Accepted : 15.11.2015

Members of the Research Forum Associated Authors:

${ }^{1}$ Department of Vegetable Science, College of Horticulture, University of Horticultural Sciences, BAGALKOT (KARNATAKA) INDIA

Author for correspondence S.M. KALE

Department of Horticulture, College of Horticulture, University of

Horticultural Sciences, BAGALKOT (KARNATAKA) INDIA

Email : kalesatishkumar@gmail.com
THEASIAN JOURNALOF HORTICULTURE

Volume 10 | Issue 2 | December, 2015 | 242-245 Visit us -www.researchjournal.co.in

\title{
Varietal evaluation of some important nutritional constituents in onion (Allium cepa L.) genotypes
}

\section{S.M. KALE AND P. S. AJJAPPALAVARA ${ }^{1}$}

ABSTRACT : Total 44 onion genotypes were analysed for total soluble solids, dry matter content, pyruvic acid, calcium, fibre, magnesium and vitamin $\mathrm{C}$. The TSS range observed was $8.36^{\circ} \mathrm{Brix}$ (OG-42) to $22.60^{\circ} \mathrm{Brix}$ (OG-3), dry matter content ranged from 14.61 per cent (OG-23) to 22.50 per cent (OG-13), pyruvic acid was $4.15 \mu$ moles/g (OG-24) to $6.10 \mu$ moles/g (OG-3). The maximum calcium content was recorded in genotype OG-28 $(20.86 \mathrm{mg} / 100 \mathrm{~g})$, fibre ranged from $8.00 \mathrm{mg} / 100 \mathrm{~g}$ (OG-17) to $28.33 \mathrm{mg} / 100 \mathrm{~g}$ (OG-44), Amount of magnesium is ranged from $0.46 \mathrm{mg} /$ $100 \mathrm{~g}$ (OG-17) to $6.23 \mathrm{mg} / 100 \mathrm{~g}$ (OG-2) and vitamin. C content ranged from $57.00 \mathrm{mg} / 100 \mathrm{~g}$ in OG5 to $95.93 \mathrm{mg} / 100 \mathrm{~g}$ (OG-3).

KEY WORDS : Allium cepa L. TSS, Dry matter, Pyruvic acid, Calcium, Fibre, Magnesium, Vitamin C.

HOW TO CITE THIS ARTICLE : Kale, S.M. and Ajjappalavara, P.S. (2015). Varietal evaluation of some important nutritional constituents in onion (Allium cepa L.) genotypes. Asian J. Hort., 10(2) : 242-245. 